\title{
Examining Energy Consumption and Carbon Emissions of Microbial Induced Carbonate Precipitation Using the Life Cycle Assessment Method
}

\author{
Xuejie Deng ${ }^{1,2, *}, \mathrm{Yu} \mathrm{Li}^{1}{ }^{1}$, Hao Liu ${ }^{1}$, Yile Zhao ${ }^{1}$, Yinchao Yang ${ }^{2}$, Xichen $\mathrm{Xu}^{3}$, Xiaohui Cheng ${ }^{3}$ \\ and Benjamin de Wit ${ }^{4}(\mathbb{D}$
}

check for

updates

Citation: Deng, X.; Li, Y.; Liu, H.; Zhao, Y.; Yang, Y.; Xu, X.; Cheng, X.; Wit, B.d. Examining Energy Consumption and Carbon Emissions of Microbial Induced Carbonate Precipitation Using the Life Cycle Assessment Method. Sustainability 2021, 13, 4856. https://doi.org/ $10.3390 /$ su13094856

Academic Editor: Castorina Silva Vieira

Received: 30 March 2021

Accepted: 22 April 2021

Published: 26 April 2021

Publisher's Note: MDPI stays neutral with regard to jurisdictional claims in published maps and institutional affiliations.

Copyright: (c) 2021 by the authors. Licensee MDPI, Basel, Switzerland. This article is an open access article distributed under the terms and conditions of the Creative Commons Attribution (CC BY) license (https:/ / creativecommons.org/licenses/by/ $4.0 /)$.
1 School of Energy and Mining Engineering, China University of Mining and Technology, Beijing 100083, China; liyu_cumtb@163.com (Y.L.); liuhaobj@126.com (H.L.); zhaoyile_cumtb@163.com (Y.Z.)

2 Kailuan (Group) Co. Ltd., Tangshan 063018, China; rcglk@kailuan.com.cn

3 Department of Civil Engineering, Tsinghua University, Beijing 100084, China; xxc19@mails.tsinghua.edu.cn (X.X.); chengxh@tsinghua.edu.cn (X.C.)

4 Smith School of Business, Queen's University, Toronto, ON M5V 3K2, Canada; mr.bendewit@gmail.com

* Correspondence: dengxj@cumtb.edu.cn; Tel.: +86-18811352307; Fax: +86-010-62339060

\begin{abstract}
Microbial induced carbonate precipitation (MICP) is a new geotechnical engineering technology used to strengthen soils and other materials. Although it is considered to be environmentally friendly, there is a lack of quantitative data and objective evaluation to support conclusions about its environmental impact. In this paper, the energy consumption and carbon emissions of MICP technology are quantitatively analyzed by using the life cycle assessment (LCA) method. The environmental effects of MICP technology are evaluated from the perspectives of resource consumption and environmental impact. The results show that for each tonne of calcium carbonate produced by MICP technology, $1.8 \mathrm{t}$ standard coal is consumed and $3.4 \mathrm{t} \mathrm{CO}_{2}$ is produced, among which $80.4 \%$ of the carbon emissions and $96 \%$ of the energy consumption come from raw materials. Comparing using MICP with cement, lime, and sintered brick, the current MICP application process consumes less non-renewable resources but has a greater environmental impact. The major environmental impact that MICP has is the production of smoke and ash, with secondary impacts being global warming, photochemical ozone creation, acidification, and eutrophication. In five potential application scenarios of MICP, including concrete, sintered brick, lime mortar, mine cemented backfill, and foundation reinforcement, the carbon emissions of MICP are 3 to 7 times greater than the emissions of traditional technologies. The energy consumption is 15 to 23 times. Based on the energy consumption and carbon emissions characteristics of MICP technology at the current condition, suggestions are given for the future research of MICP.
\end{abstract}

Keywords: microbial induced carbonate precipitation; life cycle assessment; energy consumption; carbon emissions

\section{Introduction}

Microbial induced carbonate precipitation (MICP) is a bio-mineralization process that refers to microorganisms in rock masses or soils generating calcium carbonate mineral crystals. The MICP process is naturally occurring in many circumstances and can be initiated artificially, under specific environmental and nutritional conditions, to take advantage of the good cementing properties created during the process [1,2]. MICP technology has been successfully applied in many areas of engineering, including foundation reinforcement [3,4], cultural relic restoration [5], anti-seepage and anti-leakage controls [6], heavy metal solidification [7-9], mechanical soil improvement [10-12], underground mine waste and backfill optimization [13], in addition to a broad range of prospective applications.

There are four types of MICP technology, including urea hydrolysis, denitrification, iron salt reduction reaction, and sulfate reduction reaction. MICP using urea hydrolysis is 
the most widely used of the 4 processes, having a reaction process that is relatively simple and easy to control and also one that produces a significant amount of carbonates in a short period. Therefore, MICP using urea hydrolysis has been the mainstream technology for calcium carbonate biomineralization [14]. The principal characteristic of MICP urea hydrolysis is that urea is hydrolyzed to carbonate ions by the catalysis of microbial urease. Then carbonate ions react with free calcium ions in the system to produce calcium carbonate precipitation with gelation properties. The mechanism of MICP can be summarized as Formulas (1)-(3) [4,15], and the reaction mechanism model of MICP with urea hydrolyzed bacteria is shown in Figure 1 [16].

$$
\begin{gathered}
\mathrm{CO}\left(\mathrm{NH}_{2}\right)_{2}+2 \mathrm{H}_{2} \mathrm{O} \stackrel{\text { Bacterial }}{\rightarrow} 2 \mathrm{NH}_{4}^{+}+\mathrm{CO}_{3}^{2-} \\
\mathrm{Ca}^{2+}+\mathrm{Cell} \rightarrow \mathrm{Cell}-\mathrm{Ca}^{2+} \\
\mathrm{Cell}-\mathrm{Ca}^{2+}+\mathrm{CO}_{3}^{2-} \rightarrow \text { Cell }-\mathrm{CaCO}_{3}
\end{gathered}
$$

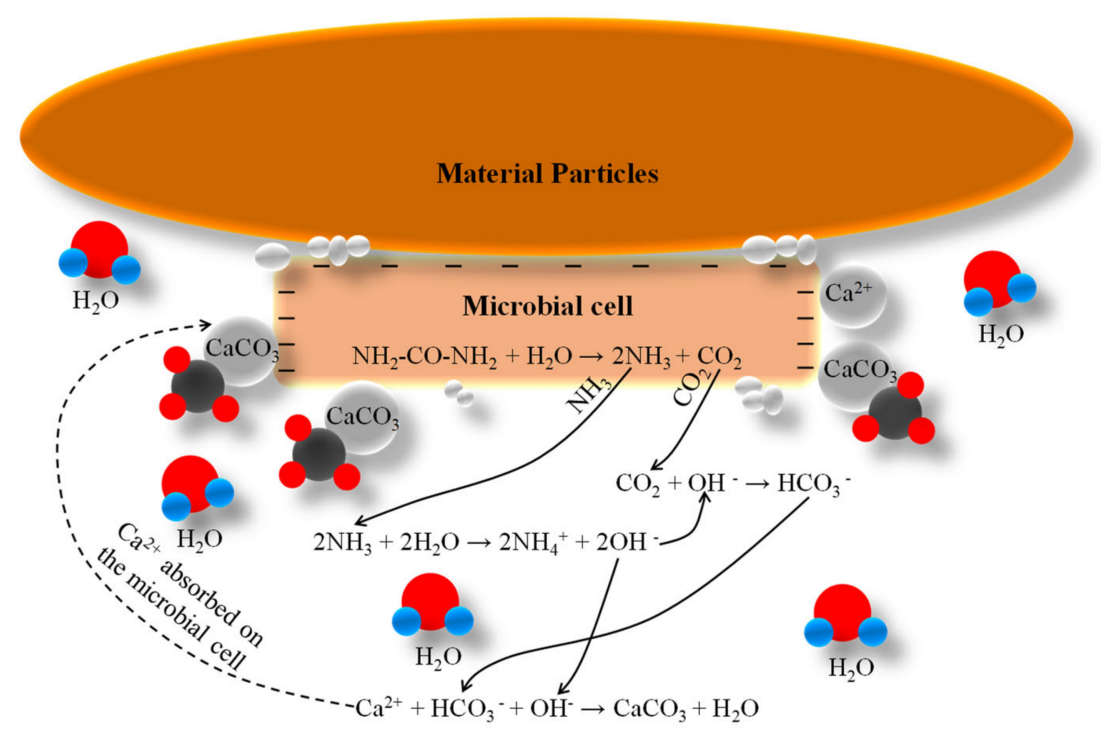

Figure 1. Reaction mechanism model of MICP with urea hydrolyzed bacteria.

Since MICP technology was first introduced, one of its biggest supporting characteristics has been its classification as "environmentally friendly". When comparing MICP to traditional cementation methods, DeJong et al. [17] concluded that MICP provided an alternative and environmentally friendly approach for soil improvement. Nader Hataf [18] used MICP technology to form barriers in waste, water, and foundations, providing an environmentally friendly method for reducing soil permeability of landfill foundations and walls. Li Meng used MICP technology to consolidate heavy metal ions in wastewater to reduce environmental pollution [19]. Gai [20] and Li [21] writes about MICP being used to improve sand and soils and refer to MICP as an environmentally friendly technology in their paper. Adharsh Rajasekar [22] points out that MICP is not $100 \%$ environmentally friendly, and the by-products of the reactions can be harmful to human health and local microbiota. To evaluate the environmental effects of MICP scientifically and objectively, energy consumption and carbon emission should be used as indicators for the quantitative analysis.

The consensus viewpoint of current MICP research is that the technology is environmentfriendly, but this viewpoint is often reached without providing evaluations that are thoroughly supported by specific, objective, and systematic methods. This contrasts with other industries where research completed on energy consumption and carbon emissions is often supported by evaluation methods, such as life cycle assessment (LCA), which is a quantitative study of energy consumption and carbon emissions [23]. LCA has been 
applied to various industries, including cement [24], concrete [25], and steel manufacturing, and the strong results achieved support its use for evaluating MICP. Implementing MICP treatment can be applied through different methods, including the grouting method $[19,26]$, the soaking method [27,28], and the mixing method [13], all, of which have relatively low energy consumption. In addition to having lower energy consumption, MICP technology does not directly produce harmful environmental gases, and beyond this, the technology can absorb carbon dioxide from the air by forming carbonate ions to participate in the reaction. However, though there are not direct environmental impacts of applying MICP technology, creating the raw materials used in $\mathrm{MICP}$-including urease bacteria, urea, and calcium-entails significant energy consumption and carbon emissions.

In this paper, LCA is used to study the energy consumption and carbon emissions of MICP technology. From the perspective of resource consumption and environmental impact, the energy consumption and carbon emissions of MICP technology in different application scenarios are quantitatively analyzed, and the environmental impacts of MICP technology are evaluated. The research conclusion of this paper is not to deny the technical advantages of MICP but to point out the future research direction of MCIP based on its energy consumption and carbon emission performance under the current technical level.

\section{Materials and Methods}

LCA is an assessment method that performs "cradle" to "grave" evaluations, which can be used to thoroughly assess the environmental impacts of technologies [24,29]. LCA includes analyzing the extraction of raw materials, the quantification of energy utilization, the transportation of materials, the production process, and long-term and disposal impacts. As defined in International Organization for Standardization (ISO) 14040:2006 [23], LCA is a compilation and assessment of inputs, outputs, and the potential environmental impacts throughout the life cycle of a product. The LCA method is a systematic multi-stage approach and a reliable assessment tool that is divided into four parts: (a) goal and scope definition; (b) inventory analysis; (c) impact assessment of the process; and (d) analysis of the results.

\subsection{Energy Consumption and Carbon Emission Analysis of MICP Technology Based on LCA}

(1) Goal and scope

The LCA method is used in this research to study the energy consumption and carbon emissions of MICP technology and evaluate the environmental effects in different applied scenarios using various strength levels.

(2) System boundaries

The core functional product of MICP technology is calcium carbonate $\left(\mathrm{CaCO}_{3}\right)$. When evaluating the life cycle of $\mathrm{MICP}, \mathrm{CaCO}_{3}$ produced by $\mathrm{MICP}$ is used as the evaluation index, and the functional unit is set to 1 tonne $\mathrm{CaCO}_{3}$. The system boundaries of MICP technology in the analysis process are shown in Figure 2.

(3) Analysis and assessment

Based on the system boundaries of MICP technology, a quantitative inventory analysis is conducted for raw material consumption, carbon emissions, and energy consumption within the system. On this basis, by calculating environmental potential (EP) and abiotic depletion potential (ADP), the impact of MICP technology on the environment in different applied scenarios is evaluated. 


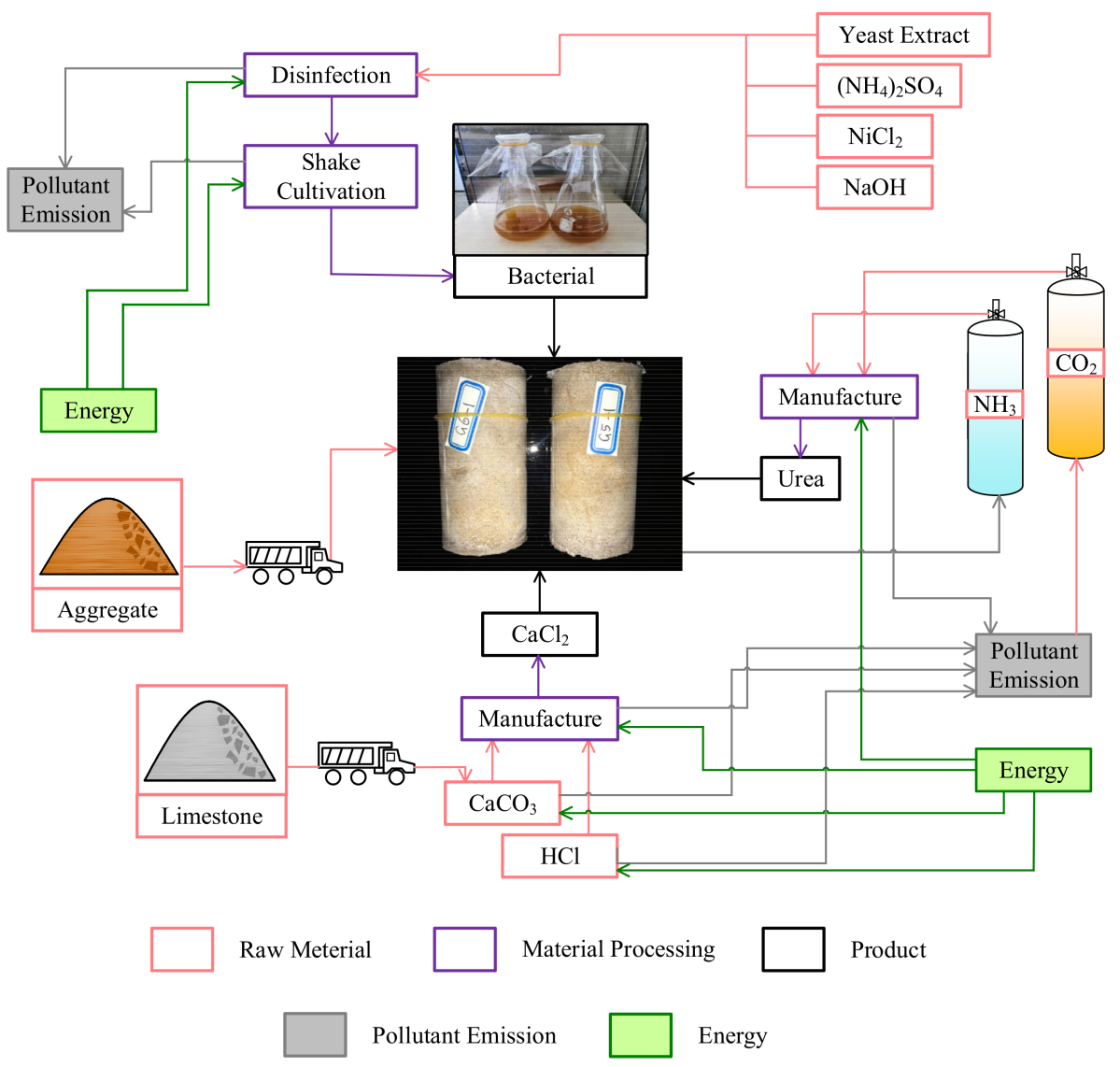

Figure 2. The system boundaries of MICP technology.

\subsection{Environmental Impact Assessment Method of MICP}

\subsubsection{Abiotic Depletion Potential}

Natural resources are limited, and as an index of LCA evaluation, abiotic depletion potential (ADP) is a value assigned to a product that is influenced by the amount and type of mineral resources the product consumes in its production. ADP is used to transform the different combinations of consumed resources into a unified reference value that can be used for comparative analyses. The calculation method is shown in Formula (4):

$$
A D P=\Sigma[M C(i) \times E F(i)]
$$

where $A D P$ is the total non-renewable resource potential of the constituent elements used to produce the product; $M C(i)$ is the generalized material consumption value of element $i$; $E F(i)$ is the equivalent factor of element $i$.

The equivalent factor of ADP is shown in Table 1.

Table 1. The equivalent factor of ADP.

\begin{tabular}{cccccc}
\hline \multirow{2}{*}{ Item } & \multirow{2}{*}{$\begin{array}{c}\text { Unified } \\
\text { Reference }\end{array}$} & \multicolumn{4}{c}{ Category } \\
\cline { 3 - 6 } & kg oil & Limestone & Gypsum & Iron Powder & Clay \\
\hline \multirow{2}{*}{ ADP } & 1.0762 & 3.0141 & 3.1283 & 2.06 \\
\hline
\end{tabular}

\subsubsection{Environmental Impact Potential Value}

In the analysis of the MICP system and carbon emissions, other pollutant emissions affect the environment. Therefore, the calculated environmental impact potential value 
refers to the comprehensive index of total emission impacts of various pollutants as seen in all environments of the entire product system, which can be calculated by Formula (5):

$$
E P(j)=\Sigma E P(j)_{i}=\Sigma\left[Q(j)_{i} \times E F(j)_{i}\right]
$$

where $E P(j)$ is the generalized environmental impact potential value of environment $j$ within the production system; $E P(j)_{i}$ is the environmental impact potential value of the pollutant emission $i$ on the environment $j ; Q(j)_{i}$ is the discharge amount of element $i$ on the environment $j$; $E F(j)_{i}$ is the equivalent factor of the environmental impact potential value of element $i$ on the environment $j$.

The determination of equivalent factors varies with different environmental impacts, and it usually takes one element as a reference to calculate the relative size of other elements.

According to the methods proposed by the International Standardization Organization (ISO), the International Society for Environmental Toxicology (SETAC), and the Technical University of Denmark, the types of environmental impacts considered in this study are global warming (GW) [30], acidification (AC), eutrophication (NE) [31], photochemical ozone creation (POC) [32,33], and smoke and ash (SA). The main environmental impact types and their corresponding equivalent factors are shown in Table 2.

Table 2. Environmental impact types and equivalent factors.

\begin{tabular}{|c|c|c|c|c|c|}
\hline \multirow{2}{*}{ Item } & \multirow{2}{*}{$\begin{array}{c}\mathrm{GW} \\
\left(\mathrm{g} \mathrm{CO}_{2} \cdot \text { Eq./g) }\right.\end{array}$} & AC & $\mathrm{NE}$ & POC & SA \\
\hline & & $\left(\mathrm{g} \mathrm{SO}_{2} \cdot\right.$ Eq./g) & $\left(\mathrm{g} \mathrm{NO}_{3} \cdot\right.$ Eq./g) & $\left(\mathrm{g} \mathrm{C}_{2} \mathrm{H}_{2} \cdot\right.$ Eq./g) & $(g / g)$ \\
\hline $\mathrm{CO}_{2}$ & 1 & & & & \\
\hline $\mathrm{SO}_{2}$ & & 1 & & 0.048 & \\
\hline $\mathrm{NO}_{X}$ & 320 & 0.7 & 1.35 & 0.028 & \\
\hline $\mathrm{CO}$ & 2 & & & 0.027 & \\
\hline COD & & & 0.23 & & \\
\hline $\mathrm{CH}_{4}$ & 25 & & & 0.006 & \\
\hline PM & & & & & 1 \\
\hline
\end{tabular}

The calculated environmental impact potential values are compared after standardization and weighted assessment.

\section{Life Cycle Inventory Analysis of MICP}

\subsection{List of Raw Material Consumption}

According to Formulas (1)-(3), $1 \mathrm{~mol}$ of $\mathrm{CO}\left(\mathrm{NH}_{2}\right)_{2}$ and $1 \mathrm{~mol}$ of $\mathrm{Ca}^{2+}$ can produce $1 \mathrm{~mol}$ of cell $\mathrm{CaCO}_{3}$ under the condition of complete reaction. Thus 0.64 tonnes of urea and 0.4 tonnes of $\mathrm{Ca}^{2+}$ are needed to produce 1 tonne of calcium carbonate. The ratio of bacterial solution to nutrient salts (urea and $\mathrm{CaCl}_{2}$ ) is assumed to $1: 10$. The raw materials used in the whole reaction process of MICP are bacteria solution, urea, and calcium chloride.

(1) Bacterial solution

Bacteria and culture medium are needed to prepare the bacterial solution. The bacteria used in this study is Sporosarcina pasteurii, which has a highly effective urease activity and is one of the most popular bacteria in MICP studies [20]. Each liter of the culture medium contains $20 \mathrm{~g}$ of yeast extract, $10 \mathrm{~g}$ of $\left(\mathrm{NH}_{4}\right)_{2} \mathrm{SO}_{4}$, and $10 \mu \mathrm{mol}$ of $\mathrm{NiCl}_{2}$. The $\mathrm{pH}$ of the culture medium is adjusted to a value of about 8.5-9 by using sodium hydroxide solution.

(2) Urea

The theoretical preparation process of urea is shown in Formula (6):

$$
2 \mathrm{NH}_{3}+\mathrm{CO}_{2} \stackrel{\text { high temperature and high pressure }}{\rightarrow} \mathrm{CO}\left(\mathrm{NH}_{2}\right)_{2}+\mathrm{H}_{2} \mathrm{O}
$$


The mass ratio of $\mathrm{CO}\left(\mathrm{NH}_{2}\right)_{2}, \mathrm{NH}_{3}$, and $\mathrm{CO}_{2}$ is 64:40:44 under complete reaction conditions, which means 0.4 tonnes of $\mathrm{NH}_{3}$ and 0.44 tonnes of $\mathrm{CO}_{2}$ are needed to produce 0.64 tonnes of $\mathrm{CO}\left(\mathrm{NH}_{2}\right)_{2}$.

(3) Calcium chloride

The theoretical preparation process of $\mathrm{CaCl}_{2}$ is shown in Formula (7):

$$
\mathrm{CaCO}_{3}+2 \mathrm{HCl} \rightarrow \mathrm{CaCl}_{2}+\mathrm{H}_{2} \mathrm{O}+\mathrm{CO}_{2} \uparrow
$$

The mass ratio of $\mathrm{CaCl}_{2}, \mathrm{CaCO}_{3}$, and $\mathrm{HCl}$ is 1.08:1:0.72 under complete reaction conditions, which means it takes 1 tonne of $\mathrm{CaCO}_{3}$ and 0.72 tonnes of $\mathrm{HCl}$ to produce 1.08 tonne of $\mathrm{CaCl}_{2}$.

The list of raw material consumption to produce 1 tonne of cell $\mathrm{CaCO}_{3}$ is shown in Table 3.

Table 3. List of raw material consumption.

\begin{tabular}{ccccccccc}
\hline Raw Material & $\mathrm{NH}_{3}$ & $\mathrm{CO}_{2}$ & $\mathrm{CaCO}_{3}$ & $\mathbf{H C l}$ & $\mathbf{H}_{2} \mathrm{O}^{*}$ & $\begin{array}{c}\text { Yeast } \\
\text { Extract }\end{array}$ & $\mathrm{NH}_{4} \mathrm{Cl}$ & $\mathbf{N i C l}_{2}$ \\
\hline $\begin{array}{c}\text { Unit Consumption } \\
\mathrm{kg} / \mathrm{t}\end{array}$ & 400 & 440 & 1000 & 720 & 400 & 20 & 10 & 0.00124 \\
\hline
\end{tabular}

* The $\mathrm{H}_{2} \mathrm{O}$ refers to the water consumed to hydrolyze urea, excluding the water in urea solution, calcium chloride solution, and bacterial solution. ${ }^{* *}$ The ratio of materials in the medium solution shown in Table 3 is the optimal ratio during the experiment.

\subsection{List of Carbon Emissions}

\subsubsection{Carbon Emissions of the Bacterial Culture Process}

Carbon emissions of the bacterial culture process $\left(C_{b}\right)$ mainly come from the respiration during the bacterial growth and the electrical consumption of equipment used for bacterial cultivation. However, the carbon emission produced by respiration is very small; it is negligible in the calculation. Taking a 1 tonne fermenter as an example, the electrical energy consumed by various instruments during the bacterial cultivation is shown in Table 4 .

Table 4. The list of instruments used in the bacterial culture process.

\begin{tabular}{|c|c|c|c|c|c|c|}
\hline Instruments & $\begin{array}{c}\text { Steam } \\
\text { Generator }\end{array}$ & Fermenter & $\begin{array}{c}\text { Air } \\
\text { Compressor }\end{array}$ & $\begin{array}{l}\text { Air-Drying } \\
\text { Machine }\end{array}$ & Display Panel & $\begin{array}{l}\text { Water Production } \\
\text { Equipment }\end{array}$ \\
\hline Power $(\mathrm{kW})$ & $48 / 24$ & 0.06 & 15 & 0.6 & 0.5 & 7 \\
\hline Service time $(\mathrm{h})$ & $2.5 / 0.5$ & 16 & 20 & 20 & 0.7 & 20 \\
\hline
\end{tabular}

The carbon emission of the bacterial culture process can be calculated by Formula (8):

$$
C_{b}=\left(\Sigma W_{i} \times t\right) \times k_{1}
$$

where $W_{i}$ is the power of the instrument $i, \mathrm{~kW} ; t$ is the time, $\mathrm{h} ; k_{1}$ is the carbon emissions generated by $1 \mathrm{MJ}$ electricity, $317 \mathrm{~g}$.

According to Formula (8), $C_{b}$ of $1000 \mathrm{~L}$ bacterial solution is $667,955.77 \mathrm{~g}$.

\subsubsection{Carbon Emissions of Urea and $\mathrm{CaCl}_{2}$}

The energy consumption of urea and calcium chloride $\left(C_{m u}\right.$ and $\left.C_{m c a}\right)$ mainly includes coal consumption and electricity consumption, resulting from the consumption of raw materials and the production process. The raw materials and energy consumption in the production process of urea and calcium chloride are shown in Table 5 [34]. 
Table 5. Raw materials and energy consumption of urea and calcium chloride.

\begin{tabular}{ccccc}
\hline Item & \multicolumn{2}{c}{ Raw Materials (t) } & $\begin{array}{c}\text { Coal Consumption } \\
(\mathbf{k g})\end{array}$ & $\begin{array}{c}\text { Electricity Consumption } \\
(\mathbf{k W h})\end{array}$ \\
\hline Urea (t) & $\mathrm{NH}_{3}$ & 0.58 & 1555.49 & 1032.57 \\
& $\mathrm{CO}_{2}$ & 0.785 & & 1593.6138 \\
$\mathrm{CaCl}_{2}(\mathrm{t})$ & $\mathrm{HCl}(31 \%)$ & 2.33 & 1000 & \\
& Limestone & 1.42 & & \\
\hline
\end{tabular}

According to Table 5, Formulas (4) and (5), each tonne of urea and calcium chloride produce 0.42 tonnes and 2.79 tonnes of $\mathrm{CO}_{2}$, respectively. Under complete reaction conditions, MICP technology needs 0.64 tonnes of urea and 1.08 tonnes of calcium chloride to produce 1 tonne of $\mathrm{CaCO}_{3}$, and the carbon emission is 2.74 tonnes.

\subsubsection{Carbon Emissions from the Reaction Process of MICP}

The entire reaction process of MICP occurs naturally and is mainly dominated by bacteria. In the reaction process, no extra energy is required, and only raw materials are constantly consumed. According to Formulas (1) and (2), all $\mathrm{CO}_{2}$ generated by urea hydrolysis changes to $\mathrm{CO}_{3}{ }^{2-}$ under the complete reaction condition. This means the carbon emission from the reaction process of $\operatorname{MICP}\left(C_{p}\right)$ is 0 .

\subsubsection{Total Carbon Emissions}

Total carbon emissions of MICP $(C)$ include the $\mathrm{CO}_{2}$ of the bacterial culture process $\left(C_{b}\right)$, the production of raw materials $\left(C_{m u}\right.$ and $\left.C_{m c a}\right)$, and the reaction process of $\operatorname{MICP}\left(C_{p}\right)$ :

$$
C=C_{b}+C_{m u}+C_{m c a}+C_{p}
$$

According to Formula (9), the total amount of carbon emissions of MICP to generate 1 tonne of $\mathrm{CaCO}_{3}$ is $3399.5 \mathrm{~kg}$.

\subsection{Comprehensive Energy Consumption}

The comprehensive energy consumption $(E)$ of each tonne of calcium carbonate produced by MICP is obtained by converting the coal consumption and electricity consumption into standard coal, as shown in Formula (10):

$$
E=E_{C} \times k_{2}+E_{E} \times k_{3}
$$

where $E$ is the comprehensive energy consumption of each tonne of calcium carbonate produced by MICP technology, $\mathrm{kg}$ coal equivalent (kgce); $E_{C}$ is the coal consumed by MICP technology, $\mathrm{kg} ; E_{E}$ is the electricity consumed by MICP technology, $\mathrm{kWh} ; k_{2}$ is the standard coal coefficient of raw coal, $0.7143 ; k_{3}$ is the standard coal coefficient of electricity, $0.1229 \mathrm{~kg} / \mathrm{kWh}$.

According to the calculation, $1847.3 \mathrm{kgce}$ of energy is consumed to produce 1 tonne of $\mathrm{CaCO}_{3}$ with MICP technology.

\section{Results and Discussion}

\subsection{LCA of MICP Technology}

\subsubsection{Carbon Emissions and Energy Consumption Analysis of MICP}

The results of carbon emissions and energy consumption inventory analysis of MICP technology are shown in Figure 3. 


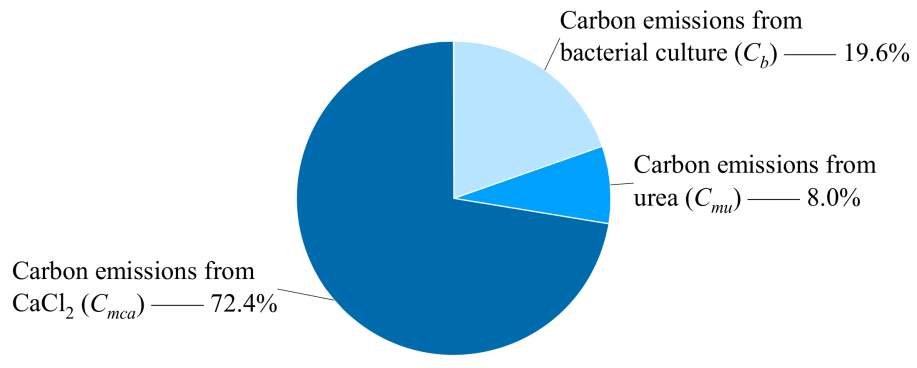

(a)

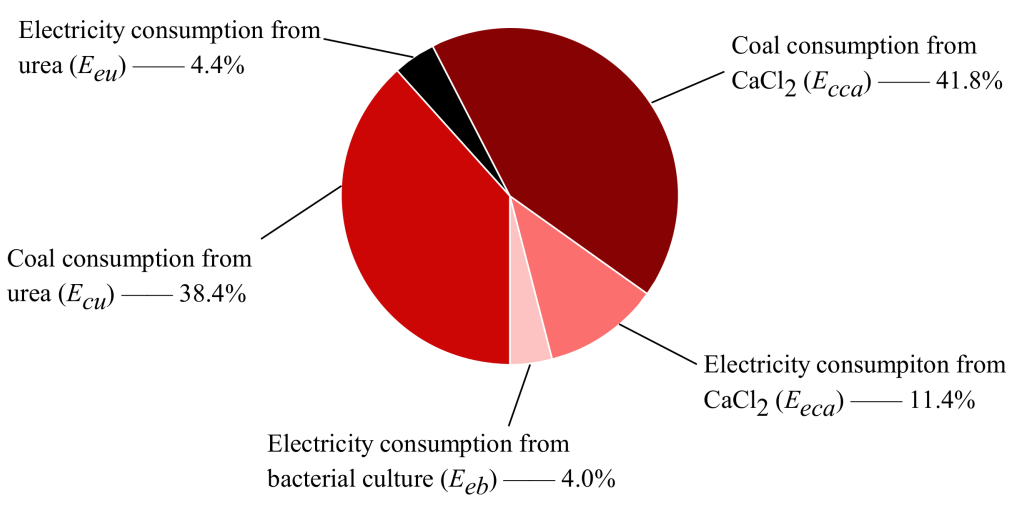

(b)

Figure 3. Carbon emissions and energy consumption ratio of MICP. (a) Carbon emissions; (b) energy consumption.

Figure 3 shows that the raw materials of MICP play an important role in carbon emissions and energy consumption. The carbon emissions of MICP mainly come from raw materials, accounting for $80.4 \%$ of the total emissions. The rest of the carbon emissions are from the bacterial culture process, accounting for $19.6 \%$. In terms of energy consumption, the coal consumption ( $E_{c u}$ and $E_{c c a}$ ) of MICP accounts for $80.2 \%$ of the total energy consumption, and the electricity consumption $\left(E_{e u}, E_{e c a}, E_{e p}\right.$ and $\left.E_{e b}\right)$ accounts for $19.8 \%$. The coal consumption is all from raw materials, and the electricity consumption is $79.8 \%$ from raw materials. The energy consumption of raw materials $\left(E_{c u}, E_{e u}, E_{c c a}\right.$ and $\left.E_{e c a}\right)$ accounted for $96.0 \%$ of the total energy consumption. Furthermore, the raw materials are high carbon emission and high-energy consumption materials. The carbon emissions of calcium sources account for $72.4 \%$ of the carbon emissions of the entire MICP process. The energy consumption of calcium source and urea account for $53.2 \%$ and $42.8 \%$ of the total energy consumption, respectively. The energy consumption of the bacterial culture process only accounts for $4.0 \%$ of the total energy consumption.

To reduce the energy consumption and carbon emissions of MICP technology, many scholars tried other materials to replace calcium chloride and urea. Chen [35] used the pig urine mainly containing ammonia and urea instead of pure urea. The permeability, porosity, and other mechanical properties of the quartz-sand column were improved obviously by $\mathrm{MICP}$ with the pig urine. The energy consumption and carbon emissions were reduced by $43 \%$ and $8 \%$, respectively, because of using pig urine. Choi [36] made the calcium source by mixing the eggshell and vinegar at a mass ratio of 1:8. The calcium carbonate content of the eggshell is $94 \%$, and the MICP application effect was good. Cheng [37] used seawater as a calcium source of MICP, and the strength of the sand column increased significantly after repeated treatments with seawater. This research show that energy consumption and carbon emissions can be significantly reduced by using animal waste, eggshell, and seawater in place of industrial urea and calcium sources. Therefore, using organic calcium sources and urea provides a feasible solution to the problems of high-energy consumption 
and high carbon emissions of MICP raw materials. However, the research in this area is far from mature and more research is needed in the future.

\subsubsection{The Relationship between MICP Strength Level and $\mathrm{CaCO}_{3}$ Content}

The strength level indicated by the unconfined compressive strength (UCS) of MICP samples directly affects its energy consumption and carbon emissions. The strength level of MICP is related to its calcium carbonate content (CCC). To obtain the quantitative relationship between the UCS and CCC of MICP, the data published by international scholars $[10,28,38-45]$ are summarized and analyzed. The results are shown in Figure 4 and Table 6.

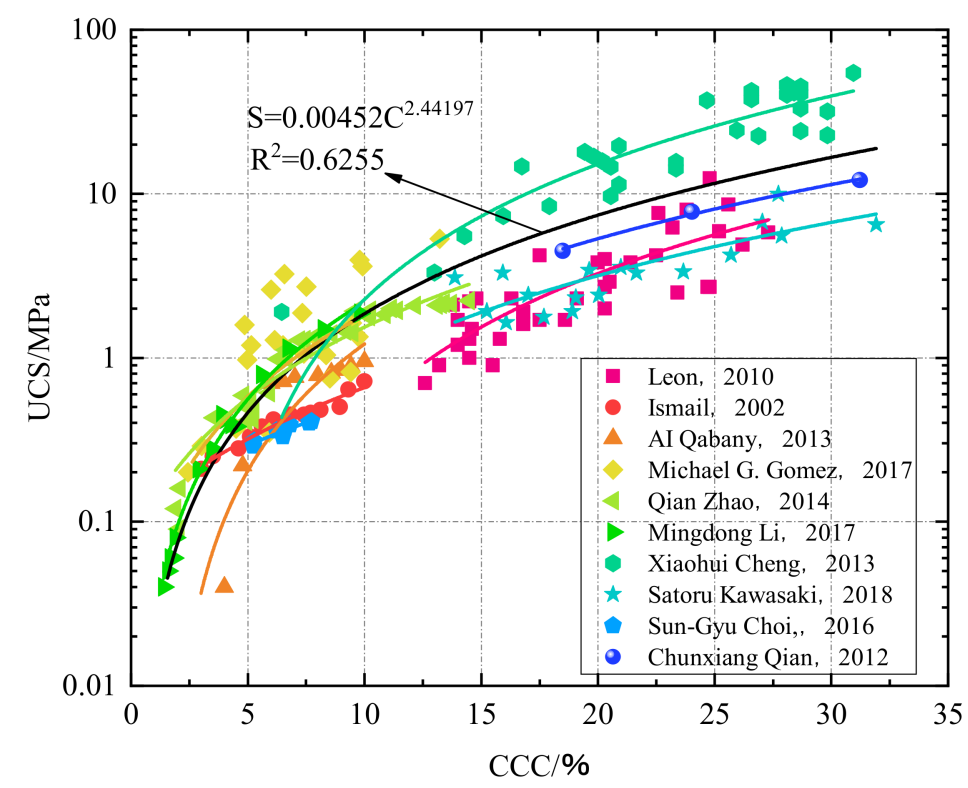

Figure 4. Relationship between calcium carbonate content and strength level of MICP samples. The vertical scale is a logarithmic scale; the horizontal scale is a linear scale.

Table 6. Summarization of scholars on calcium carbonate content and strength level.

\begin{tabular}{|c|c|c|c|c|c|c|c|}
\hline Scholar & Bacteria & $\begin{array}{l}\text { Calcium } \\
\text { Sources }\end{array}$ & Materials & Methods & $\begin{array}{c}\text { Regression } \\
\text { Equation }\end{array}$ & $\mathbf{R}^{2}$ & Reference \\
\hline Leon & Sporosarcina pasteurii & $\mathrm{CaCl}_{2}$ & Quarry sand & Grouting & $S=0.00166 C^{2.5419}$ & 0.5208 & [39] \\
\hline Ismail & Sporosarcina pasteurii & $\mathrm{CaCl}_{2}$ & RT sand & Grouting & $S=0.06421 C^{1.0020}$ & 0.9170 & [40] \\
\hline AI Qabany & Sporosarcina pasteurii & $\mathrm{CaCl}_{2}$ & British sand & Grouting & $S=0.02342 C^{1.6537}$ & 0.8502 & [10] \\
\hline Michael G. Gomez & Sporosarcina pasteurii & - & Silty sand & Grouting & $S=0.0471 C^{1.7643}$ & 0.4410 & [41] \\
\hline Qian Zhao & Sporosarcina pasteurii & $\mathrm{CaCl}_{2} 2 \mathrm{H}_{2} \mathrm{O}$ & Ottawa sand & Soaking & $S=0.09639 C^{1.2163}$ & 0.9344 & [38] \\
\hline Mingdong Li & Sporosarcina pasteurii & $\mathrm{CaCl}_{2} 2 \mathrm{H}_{2} \mathrm{O}$ & Standard sand & Soaking & $S=0.03592 C^{1.7495}$ & 0.9851 & [28] \\
\hline Xiaohui Cheng & Sporosarcina pasteurii & $\mathrm{CaCl}_{2}$ & Standard sand & Grouting & $S=0.00779 C^{2.5220}$ & 0.7312 & [42] \\
\hline Satoru Kawasaki & Pararhodobacter sp. & $\mathrm{CaCl}_{2}$ & Silty sand & Grouting & $S=0.00948 C^{1.9420}$ & 0.6349 & [43] \\
\hline Sun-Gyu Choi & Bacillus sp. & $\mathrm{CaCl}_{2}$ & Ottawa sand & Grouting & $\mathrm{S}=0.0806 \mathrm{C}^{0.7961}$ & 0.8587 & [44] \\
\hline Chunxiang Qian & alkalophilic microbes & $\begin{array}{l}\text { calcium ion } \\
\text { solution }\end{array}$ & Quartz sand & Grouting & $S=0.02229 C^{1.8322}$ & 0.9931 & [45] \\
\hline
\end{tabular}

Figure 4 and Table 6 shows that the strength level of MICP technology increases significantly with the increase of $\mathrm{CCC}$, and there is a power function relationship between UCS and CCC. A representative model to describe the relationship between UCS and CCC of MICP samples can be obtained by regression analysis using all the data from these researchers, as shown in Formula (11).

$$
S=k_{4} C^{k_{5}}
$$


where $S$ is the unconfined compressive strength, $\mathrm{MPa} ; \mathrm{C}$ is the calcium carbonate content, $\%$; $k_{4}$ is the coefficient, $0.00452 ; k_{5}$ is the index, 2.44197 .

The quantitative relationship between the strength level and the CCC can provide a basis for the LCA evaluation of energy consumption and carbon emissions of MICP technology in different application scenarios.

Combined with the inventory analysis results, the energy consumption and carbon emissions corresponding to the different strength levels of the MICP are shown in Figure

Figure 5 indicates that the carbon emissions and energy consumption of MICP technology increase rapidly with the increase of the UCS of MICP samples. However, the relationships between strength level and calcium carbonate content of MICP samples are uncertain because of the different MICP materials and methods. The empirical relationship used in this research is an average and representative equation.

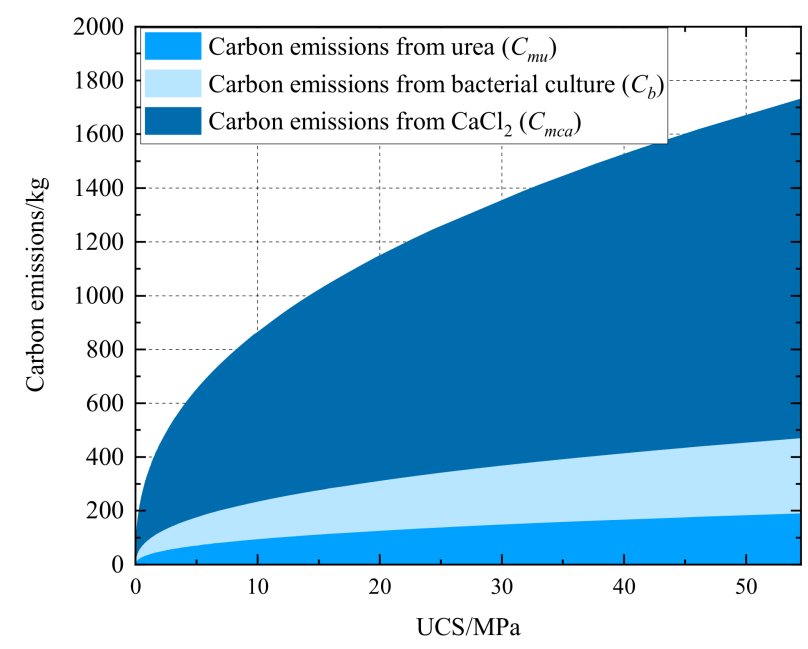

(a)

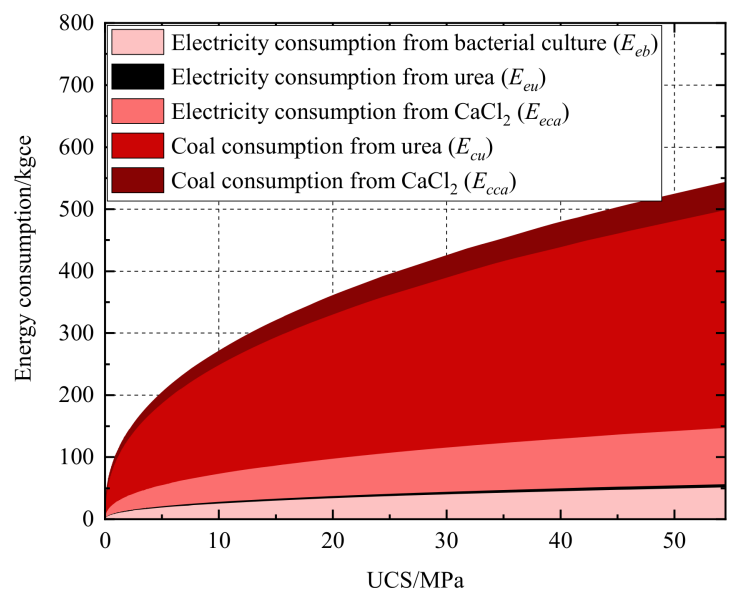

(b)

Figure 5. Carbon emissions and energy consumption versus strength levels of MICP samples. (a) Carbon emissions; (b) energy consumption.

4.2. Carbon Emissions and Energy Consumption of MICP in Different Application Scenarios 4.2.1. Applications of MICP to Replace the Cement Mortar for Concrete

Cement is a common binder, which is widely used in the construction industry [46]. However, using cement has the problem of huge energy consumption and environmental pollution [24]. Replacing cement is one of the important potential applications of MICP technology. In addition, many scholars believe that MICP is a more environmentally friendly technology than cement. 
The carbon emissions and energy consumption of cement come from the manufacturing process, transportation, fuels, and electricity [47]. The manufacturing process mainly refers to the calcination process of cement. Because $\mathrm{CaCO}_{3}, \mathrm{SiO}_{2}, \mathrm{Al}_{2} \mathrm{O}_{3}$, and $\mathrm{Fe}_{2} \mathrm{O}_{3}$ are decomposed in the clinker under high-temperature conditions [48], a large amount of $\mathrm{CO}_{2}$ is produced in this process. In the transportation process, it is assumed that all raw materials are transported by rail to the factory with a transportation distance of $100 \mathrm{~km}$. The electricity consumption in cement production includes raw material mining, crushing, pre-homogenization, grinding, homogenization, clinker calcination, coal grinding, cement grinding, transportation, etc.

The fuel is mainly coal in the calcination process of cement production. Coal combustion gives off heat but produces many carbon dioxide emissions. The functional unit in this research is set to 1 tonne of cement, and the carbon emissions and energy consumption of cement production are shown in Table 7 [49].

Table 7. List analysis of cement.

\begin{tabular}{ccc}
\hline \multicolumn{2}{c}{ Cement Grade (MPa) } & $\mathbf{5 2 . 5}$ \\
\hline Raw material (kg/t cement) & 1656.54 \\
\hline & Manufacture process & 835,550 \\
Carbon emission ( $/ \mathrm{t}$ cement) & Transportation & 52,545 \\
& Electricity & 150,648 \\
& Fuel(coal) & 2814 \\
& Total & $1,041,557$ \\
\hline \multirow{2}{*}{ Energy consumption } & Coal consumption & $3,146,042$ \\
& (kJ/t cement) & \\
& Electricity consumption & $475,229.4$ \\
& (kJ/t cement) & 123.57 \\
\hline
\end{tabular}

Table 7 shows that the carbon emissions from cement mainly come from the manufacturing process, accounting for $79.9 \%$ of the total carbon emissions. Carbon emissions from transportation, electricity and fuel account for $5 \%, 14.8 \%$, and $0.3 \%$ of the total carbon emissions, respectively. The energy consumed in the cement production process is mainly coal, which accounts for $85.7 \%$ of the total energy consumption. All fuel is used in the calcination process and the drying process.

The concrete with a strength of $40 \mathrm{MPa}(\mathrm{C} 40)$ is chosen to compare the energy consumption and carbon emissions of cement mortar and MICP. The C40 concrete needs about $450 \mathrm{~kg}$ of cement per unit volume $\left(1 \mathrm{~m}^{3}\right)$, and its carbon emissions and energy consumption are $468.7 \mathrm{~kg}$ and $55.6 \mathrm{kgce}$, respectively. It can be calculated from Figure 5, to consolidate the same volume of sand and achieve the same strength level by MICP, the carbon emissions and energy consumption is $2107.5 \mathrm{~kg}$ and $1145.2 \mathrm{kgce}$, respectively. The carbon emissions and energy consumption of MICP are 4.5 times and 20.6 times of concrete, respectively. In this application scenario, the carbon emissions and energy consumption of MICP are much higher than cement mortar. MICP is not a more environmentally friendly technology. The main reason is that the raw materials used in MICP, including calcium sources and urea, are all materials with high-energy consumption and high emissions, which harm the LCA environmental evaluation of MICP.

In addition, it is noticed that increasing studies have shown that using MICP technology as an additive in concrete can significantly improve the strength and freeze-thaw resistance of the concrete [50]. In this case, the MICP is used as an admixture rather than a binder, so the environmental impact of MICP should be compared with the traditional admixture in the concrete, not with the cement itself. However, this issue is not discussed due to the limited space of the paper. 


\subsubsection{Applications of MICP to Replace the Sintered Bricks}

Sintered bricks, mainly made of clay, are one of the oldest building materials in the world. It is widely used in the civil and architectural engineering industry with advantages of cheap, durable, fire prevention, heat insulation, noise absorption, and so on [51]. However, the production of sintered bricks needs a huge amount of clay, which destroys cultivated land seriously. According to incomplete statistics, the production of bricks in China damages $467 \mathrm{~km}^{2}$ of fertile land per year, which is extremely harmful to the environment. MICP technology can be used as a potential alternative to sintering bricks.

For the sintered brick industry, the standard unit brick (SUB) is usually used as the unit to calculate the output of sintered bricks. The volume of a sintered brick is $1,462,800 \mathrm{~mm}^{3}$ $(240 \times 115 \times 53 \mathrm{~mm})$. The carbon emissions and energy consumption of sintered bricks come from the transportation process, preparation process, fuel combustion, and electricity consumption. The transportation distance is assumed to be $100 \mathrm{~km}$. In the study of this section, the functional unit of sintered brick is set as a SUB. The inventory analysis of the sintered bricks production is shown in Table 8 [52].

Table 8. Inventory analysis of sintered bricks.

\begin{tabular}{cccc}
\hline \multicolumn{2}{c}{ Item } & Unit & Consumption \\
\hline \multicolumn{2}{c}{ Raw material } & $\mathrm{kg} / \mathrm{SUB}$ & 4.64 \\
Carbon emission & $\mathrm{g} / \mathrm{SUB}$ & 330.69 \\
\hline \multirow{2}{*}{ Energy consumption } & Coal & $\mathrm{kg} / \mathrm{SUB}$ & 0.049 \\
& Electricity & $\mathrm{kWh} / \mathrm{SUB}$ & 0.16 \\
& Total & $\mathrm{kgce} / \mathrm{SUB}$ & 0.055 \\
\hline
\end{tabular}

The strength of sintered brick is $20 \mathrm{MPa}$. To produce each sintered brick, $330.69 \mathrm{~g} \mathrm{CO}_{2}$ is emitted, and $0.055 \mathrm{kgce}$ is consumed. When bio-bricks with the same size and strength are manufactured by using MICP technology, the calcium carbonate content is about $31.1 \%$, the carbon emission is $2.3 \mathrm{~kg}$ per SUB, and the energy consumption is $1.3 \mathrm{kgce}$ per SUB. The carbon emissions and energy consumption of MICP bio-bricks of the same strength level are 7 times and 23 times higher than those of sintered bricks, respectively. Therefore, the MICP technology has a worse impact on the environment than traditional sintered bricks.

However, the clay used to produce sintered bricks is a non-renewable resource, and the environmental impact of the clay consumption is not considered here. Comparing with sintered bricks, MICP consumes less non-renewable resources, and it is discussed in Section 4.3.

\subsubsection{Applications of MICP to Replace the Lime Mortar}

Lime, mainly composed of calcium oxide, is obtained by calcining natural rocks containing calcium carbonate at an appropriate temperature to decompose carbon dioxide. As one of the building materials, lime mortar is a mixture of lime, sand, and water in a certain proportion. Lime mortar is widely used in masonry and plastering layers, which requires low strength and is not easy to be damp. The use of lime may damage the water and surrounding vegetation, and lime becomes the second-largest source of greenhouse gas emissions after the cement industry [53]. MICP can be used as a potential substitute technology for lime mortar.

Limestone is the raw material of lime; the reaction principle of the lime production is shown in Formula (12):

$$
\mathrm{CaCO}_{3} \stackrel{\text { high temperature }}{\rightarrow} \mathrm{CaO}+\mathrm{CO}_{2} \uparrow
$$

The production of 1 tonne of calcium oxide needs 2 tonnes of limestone containing approximately $50 \%$ of calcium oxide and produces 0.79 tonnes of $\mathrm{CO}_{2}$ simultaneously. The carbon emissions and energy consumption of lime come from manufacturing, trans- 
portation, fuel combustion, and electricity consumption. The manufacturing process is the calcining process of limestone, as shown in Equation (12). In the transportation process, it is assumed that all raw materials are transported to the factory by rail, and the transportation distance is $100 \mathrm{~km}$. Fuel combustion and electricity consumption refers to the heat and electricity supply during the process. The functional unit is set to 1 tonne. The carbon emissions and energy consumption of lime produced by different lime kilns are shown in Table 9.

Table 9. Inventory analysis of different lime kilns.

\begin{tabular}{|c|c|c|c|c|c|c|c|}
\hline Limekilns & $\begin{array}{l}\text { Rotary } \\
\text { Kiln }\end{array}$ & $\begin{array}{c}\text { Maliz } \\
\text { Shaft Kiln }\end{array}$ & $\begin{array}{l}\text { Sleeve } \\
\text { Kiln }\end{array}$ & $\begin{array}{l}\text { Gas-Burning } \\
\text { Shaft Kiln }\end{array}$ & $\begin{array}{l}\text { Mechanized } \\
\text { Shaft Kiln }\end{array}$ & $\begin{array}{l}\text { Sinopec } \\
\text { Shaft Kiln }\end{array}$ & $\begin{array}{l}\text { Other } \\
\text { Kilns }\end{array}$ \\
\hline Manufacture process/g & 790,000 & 790,000 & 790,000 & 790,000 & 790,000 & 790,000 & 790,000 \\
\hline Transportation/g & 63,440 & 63,440 & 63,440 & 63,440 & 63,440 & 63,440 & 63,440 \\
\hline Fuel consumption/kg & 170 & 126 & 140 & 162 & 145 & 140 & 146 \\
\hline $\begin{array}{c}\text { Electricity } \\
\text { consumption } / \mathrm{kWh}\end{array}$ & 57 & 44 & 44 & 47 & 26 & 6 & 11 \\
\hline
\end{tabular}

Regardless of the lime kiln, the energy consumption and carbon emissions of lime production are very close. The average energy consumption of lime is $149.3 \mathrm{kgce}$ per tonne, and the average carbon emission is about $900 \mathrm{~kg}$ per tonne. The carbon emissions produced by lime mainly come from the manufacturing process, accounting for $91.4 \%$ of the total emissions. Carbon emissions from transportation, electricity, and fuel accounted for 7.3\%, $0.02 \%$, and $1.28 \%$ of the total emissions, respectively. The main energy consumed in the lime production process is coal, which accounts for $97 \%$ of the total energy consumption, and electricity consumption only accounts for $3 \%$.

The strength of the lime mortar sample is $5 \mathrm{MPa}$, and the average date is used for calculation. The lime content per unit volume $\left(1 \mathrm{~m}^{3}\right)$ of lime mortar is $216 \mathrm{~kg}$, the energy consumption is $32.3 \mathrm{kgce}$, and the carbon emission is $193.8 \mathrm{~kg}$. To achieve the same strength level with MICP, the calcium carbonate content is $17.6 \%$, the energy consumption is $488.8 \mathrm{kgce}$, and the carbon emission is $899.5 \mathrm{~kg}$. The carbon emissions and energy consumption of MICP are 4.6 times and 15.2 times higher than those of lime mortar, respectively. Therefore, in this application scenario, MICP technology has a worse impact on the environment than lime.

However, it should be noted that lime mortar takes a long time to solidify and has poor durability after solidification, which is seriously affected by the moisture [54]. Conversely, the consolidation speed of MICP is faster, and the durability is better [50]. The performance of carbon emissions and energy consumption simply reflects environmental effects, and it does not indicate technical merits.

\subsubsection{Applications of MICP to Replace the Cement for Cemented Backfill}

The mining process involves the removal and recovery of economically valuable minerals from the crust of the earth [55]. The underground voids caused by mining activities, which may create serious environmental challenges, are expected to be filled with waste materials by a process known as backfilling technology [56]. The underground backfill can support the ground and dispose of the solid waste. It has significant environmental benefits [57]. Backfilling materials mainly include waste rock, gangue, and fly ash, and binder. The binder for backfilling is mainly cement [58]. MICP technology has the effect of cementing instead of cement, so it can be potentially used in cemented backfill mining.

The ratio of backfill materials used in a coal mine is taken as an example. This backfill material comprises 5\% cement, 20\% fly ash, 55\% gangue, and 20\% water. The strength of solidified backfill body is $2 \mathrm{MPa}$. The $1 \mathrm{~m}^{3}$ of backfill body is taken as a functional unit, the amount of cement is $155 \mathrm{~kg}$, and the carbon emissions and energy consumption are $161.4 \mathrm{~kg}$ and $19.1 \mathrm{kgce}$, respectively. 
If the MICP is used to replace the cement in backfill mining, the calcium carbonate content of the MICP backfill body with a strength of $2 \mathrm{MPa}$ is $12.1 \%$. Therefore, the carbon emission of MICP backfill is $618 \mathrm{~kg}$ per cubic meter, and the energy consumption is 335.8 kgce per cubic meter. The carbon emissions and energy consumption of MICP backfill materials are 3.8 times and 17.5 times higher than the traditional cement-based backfill materials, respectively. In the application scenario of backfill mining, MICP has no superiority in terms of life cycle environmental benefits comparing with traditional cemented backfill technology.

\subsubsection{Applications of MICP to Replace Cement Grouting for Foundation Reinforcement}

Foundation refers to the soil layer within a limited area of the building. The unreinforced natural soil layer is called the natural foundation, which is mostly very week. The strength and deformation properties of the natural foundation usually cannot meet the requirements of construction, so the natural foundation mostly needs to be reinforced. Cement grouting is a common reinforcement method. Its principle is to inject the cement slurry into the natural foundation soil to improve its mechanical properties. As one of the main application directions of MICP, MICP grouting reinforcement technology has the advantages of low grouting pressure, good diffusion performance, and low slurry viscosity.

The strength of the foundation after the cement slurry grouting treatment is about $300 \mathrm{kPa}-500 \mathrm{kPa}$. The proportion of cement slurry for grouting reinforcement should be determined according to the actual situation. Generally, $90 \mathrm{~kg}$ of cement is required for a unit volume $\left(1 \mathrm{~m}^{3}\right)$ of the cement slurry for foundation reinforcement. The carbon emission per unit volume of cement slurry is $93.7 \mathrm{~kg}$, and the energy consumption is $11.1 \mathrm{kgce}$. The carbon emission and the energy consumption of MICP grouting with the same strength level are $319.7 \mathrm{~kg}$ and $173.7 \mathrm{kgce}$, respectively. The carbon emissions of MICP grouting are 3.4 times of traditional cement grouting reinforcement, and the energy consumption is 15.6 times of cement grouting. Therefore, MICP shows no obvious advantages from the perspective of carbon emission and energy emission in the application scenario of foundation grouting reinforcement.

However, from a technical point of view, MICP grouting has higher diffusion, lower grouting pressure, and better uniformity of foundation reinforcement than traditional cement grouting. Moreover, MICP grouting is not toxic comparing with chemical grouting. Therefore, although the carbon emissions and energy consumption of MICP grouting are relatively high, its technical advantages are obvious; it has a broad development prospect.

\subsubsection{Comparison of Various Application Scenarios}

To compare energy consumption and carbon emissions of MICP with traditional technology in different application scenarios, the MICP energy consumption index $\left(k_{M E}\right)$ and MICP carbon emissions index $\left(k_{M C}\right)$ are defined. The $k_{M E}$ is the ratio of the energy consumption of MICP to that of the traditional technology in the current situation. The $k_{M E}$ is the ratio of the carbon emissions of the MICP to that of the traditional technology. When the $k_{M E}$ and $k_{M C}$ are greater than 1, it means that the environmental benefits of MICP are not superior. When the $k_{M E}$ and $k_{M C}$ are equal to 1 , it means that the environmental benefits of MICP are equivalent to those of traditional technology. When the $k_{M E}$ and $k_{M C}$ are less than 1, it means that the environmental benefits of MICP are superior in the current situation. The $k_{M E}$ and $k_{M C}$ of MICP in different application scenarios are shown in Figure 6. 


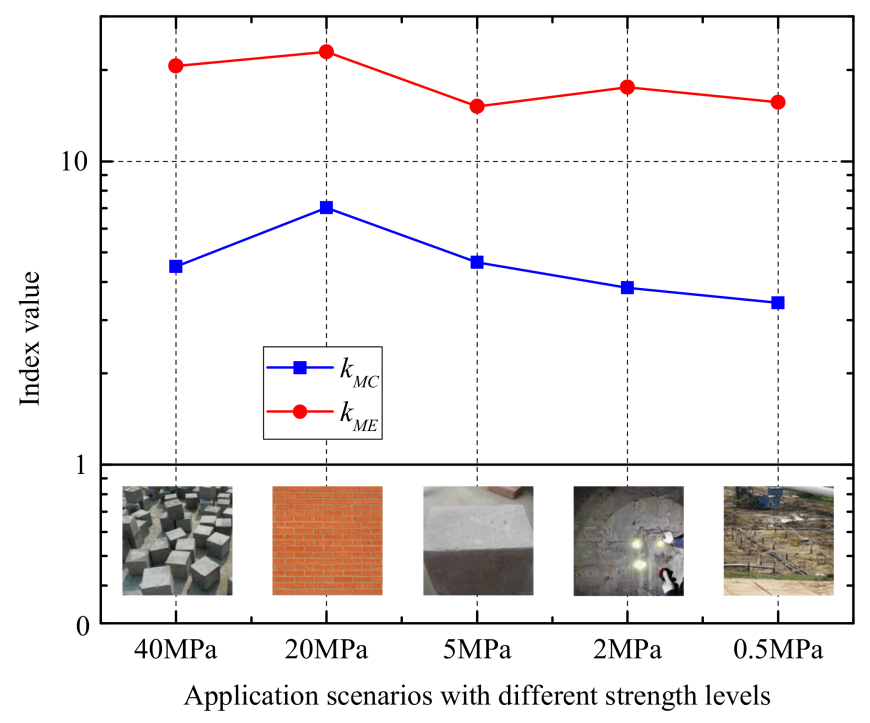

Figure 6. The $k_{M E}$ and $k_{M C}$ of MICP in different applications with different strength levels.

Under the current technical level, from the perspective of LCA, MICP does not show the advantages of environmental benefits but produces more $\mathrm{CO}_{2}$ and consumes more energy than traditional technologies. In the high-strength scenarios of $40 \mathrm{MPa}$ and $20 \mathrm{MPa}$, the $k_{M C}$ index is 4.5 and 7 , and the $k_{M E}$ index is 20.6 and 23, respectively. In the low-strength scenarios of $5 \mathrm{MPa}, 2 \mathrm{MPa}$ and $0.5 \mathrm{MPa}$, the $k_{M C}$ index is 4.6, 3.8 and 3.4, and the $k_{M E}$ index is 15.2, 17.5 and 15.6, respectively. In general, $k_{M C}$ and $k_{M E}$ values decrease with the decrease of the strength level of application scenarios. The average $k_{M C}$ and $k_{M E}$ are 4.66 and 18.38, respectively. In other words, the carbon emission of MICP is on average 4.66 times of traditional technologies, and the energy consumption is on average 18.38 times of traditional technologies.

In addition, it should be noted that most data of MICP are obtained on the laboratory scale, while the data of traditional technologies is obtained on an industrial scale. The laboratory scale and industrial scale are very different. With developing MICP technology, its energy consumption and carbon emissions will be greatly reduced. Especially after MICP is applied on the industrial scale, the environmental benefits will be more significant.

\subsection{Environmental Impact Assessment}

\subsubsection{Resource Consumption}

The five application scenarios involve four kinds of materials: cement, lime, sintered brick, and MICP. The raw materials needed to produce these four materials are shown in Table 10. Abiotic depletion potential (ADP) is used to measure the resource consumption of materials. The functional unit is set to 1 tonne. The ADP is calculated according to Formula (3), and the results are shown in Table 10.

Table 10. The raw materials requirement and ADP value of the four materials.

\begin{tabular}{cccccc}
\hline \multirow{2}{*}{ Item } & \multicolumn{3}{c}{ Raw Materials/kg } & ADP \\
\cline { 2 - 6 } & Limestone & Gypsum & Iron Powder & Clay & kg Oil \\
\hline Cement & 1232.9 & 50 & 30 & & 1571.4 \\
Lime & 2000 & & & 944 & 1944.64 \\
Sintered brick & & & & 1528.2 \\
MICP & 1420 & & &
\end{tabular}

Table 10 shows that the highest ADP value of the four materials is lime, and the MICP has the lowest ADP value. The ADP values of cement, lime, and sintered bricks are all larger than MICP, which shows that more non-renewable resources are needed to produce 
these materials. This also shows that MICP technology has advantages over cement, lime, and sintered bricks in terms of resource consumption.

\subsubsection{Environmental Impact}

In the production process of cement, lime, sintered brick, and MICP, besides carbon dioxide, other emissions are produced. The environmental impact potential value is calculated according to Table 2 and Formula (5). The functional unit is set to 1 tonne. The environmental impact potential values of cement, lime, sintered brick, and MICP on different environmental impacts are shown in Figure 7.

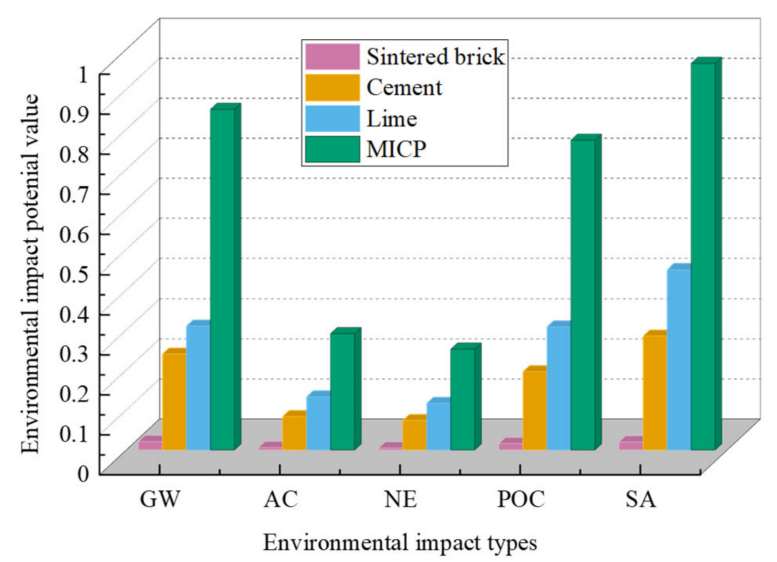

Figure 7. The environmental impact potential value of the four materials on different environmental impacts.

Figure 7 shows that cement, lime, sintered bricks, and MICP have the greatest impact on the environment in smoke and dust (SA), followed by global warming (GW) and photochemical ozone creation (POC), and the least impact is acidification (AC) and eutrophication (NE). The greatest impact of MICP on the environment in SA, which is 4 times that of cement, 2 times that of lime, and 48 times that of sintered bricks. The least environmental impact of MICP is NE, which is 3 times of cement, but 50 times of sintered bricks. Under current technical conditions, MICP has the greatest impact on various environmental impacts, while sintered bricks have the least environmental impacts.

\subsection{Limitation and Prospects}

\subsubsection{Limitation}

The energy consumption and carbon emissions studied with LCA can comprehensively and objectively reflect the environmental impact of MICP. However, this research has the following limitations:

(1) In this research, the comparison between MICP and traditional technology is carried out in terms of energy consumption and carbon emissions under the current technological level, and it does not represent the merits of the technology itself;

(2) The MICP data used in this study are all obtained on the laboratory scale, and the small scale is not good for evaluating the life cycle energy consumption and carbon emissions of MICP. Although the research conclusively shows that MICP is not as environmentally friendly as expected under the current technological conditions, it does not deny this technology. MICP has a great potential for environmental benefits with the development on the industrial scale;

(3) Within the life cycle system boundary of MICP technology, the carbon emissions and energy consumption are affected by many factors, such as the respiration of bacteria, the reacting process, the temperature, and the $\mathrm{pH}$. Because the influence of some factors is very small, necessary assumptions and simplifications are made in the research; 
(4) It is assumed that the urea is completely hydrolyzed and reacted, and the carbon emission from the reaction process is zero. However, the obvious irritating odor of ammonia gas can be smelled during the experiment, which indicates that the urea hydrolysis reaction in the MICP process is not complete. Hence, the actual MICP process needs to consume more urea, which means higher energy consumption;

(5) The treatment method for MICP technology includes grouting, soaking, and mixing. These treatment processes have different technical characteristics, as well as different energy consumption and carbon emissions. However, considering the complexity of the treatment process, it is not covered in the life cycle assessment of MICP in this study.

\subsubsection{Prospects}

Comparing with traditional cement, lime, and sintered bricks, MICP has technical advantages, such as lower $\mathrm{pH}$, lower viscosity, higher fluidity, lower grouting pressure, better heavy metal ion consolidation performance, and so on. Therefore, although MICP currently does not have an advantage in energy consumption and carbon emissions, it still has great development potential. Based on LCA results of MICP technology at the current technological level, the prospects of MICP research are given as follows:

(1) Trying diversified raw materials is an effective way to reduce the carbon emissions and energy consumption of MICP. Some organic materials, such as eggshells and livestock urine, have been studied for MICP, and it is worthy of continuing the related research;

(2) Different bacteria besides Bacillus pasteurii can be used for MICP. For example, the carbonic anhydrase mineralizing bacteria can catalyze the hydration reaction of $\mathrm{CO}_{2}$ and convert it into $\mathrm{CO}_{32}$ - to achieve the $\mathrm{CaCO}_{3}$ precipitation. This process can consume $\mathrm{CO}_{2}$, thereby significantly reducing the carbon emissions of MICP. In addition, the enzyme-induced $\mathrm{CaCO}_{3}$ precipitation is a good path to improve environmental benefits;

(3) The research of MICP on the industrial scale should be increased. Most of the current research is carried out on the laboratory scale, which is very different from the industrial scale. Usually, the greater scale, the lower unit consumption;

(4) The application scenarios of MICP should be more diverse. Besides foundation reinforcement, cultural relic restoration, anti-seepage, and anti-leakage, MICP can be applied in more situations to look for better environmental benefits;

(5) The mechanism of MICP needs to be further studied. A clear understanding of the MICP reaction mechanism is very helpful to optimize the MICP process and technical parameters by which carbon emissions and energy consumption can be reduced.

\section{Conclusions}

In this paper, the energy consumption and carbon emissions of MICP in different application scenarios are quantitatively analyzed based on LCA. The environmental effects of MICP technology at the current technology level are evaluated. The main conclusions are shown as follows:

(1) The energy consumption and carbon emissions of MICP are calculated based on LCA. Generating 1 tonne $\mathrm{CaCO}_{3}$ by MICP emits $3399.5 \mathrm{~kg}$ of $\mathrm{CO}_{2}$ and consumes $1847.2 \mathrm{kgce}$ of energy. About $80.4 \%$ of carbon emissions and $96 \%$ of the energy consumption of MICP are from its raw materials;

(2) The relationship between the strength level (UCS) and calcium carbonate content (CCC) of MICP is established. The UCS of MICP increases significantly with the increase of the CCC, and a power function relationship is found between the UCS and CCC of MICP samples. Additionally, due to various influencing factors, this relationship is an average and representative equation;

(3) The abiotic depletion potential (ADP) value of MICP is lower than that of cement, lime, sintered bricks, which indicates that MICP consumes less non-renewable resources 
and has advantages in resource consumption. The greatest environmental impact of MICP is smoke and ash, followed by global warming, photochemical ozone creation, acidification, and eutrophication. Environmental impacts of MICP are more serious than cement, lime, and sintered bricks under current technical conditions;

(4) In different application scenarios of concrete, sintered bricks, lime mortar, cemented backfill, and cement grouting foundation reinforcement, the carbon emission of MICP is on average 4.66 times of traditional technologies, and the energy consumption is averagely 18.38 times. It means the environmental benefits of the MICP technology are not superior to those of traditional technology;

(5) Although MICP currently does not have an advantage in energy consumption and carbon emissions, it still has great development potential. Suggestions are given for the future research of MICP based on LCA results.

Author Contributions: Conceptualization, X.C., X.D. and Y.L.; methodology, X.D. and Y.L.; validation, X.D.; formal analysis, Y.L., H.L. and Y.Z.; investigation, Y.L.; resources, X.D.; data curation, X.D. and Y.L.; writing—original draft preparation, X.D. and Y.L.; writing-review and editing, X.C. and B.d.W.; visualization, X.D. and X.X.; supervision, X.D. and Y.Y.; project administration, X.D.; funding acquisition, X.D. All authors have read and agreed to the published version of the manuscript.

Funding: This work was supported by the National Key R\&D Program of China (Grant Number 2018YFC0604701), the National Natural Science Foundation of China (Grant Number 51804308, 52034009), the Yue Qi Young Scholar Project (Grant Number 2020QN03), the China Postdoctoral Science Foundation (Grant Number 2020T130269, 2020M670689), and the Postdoctoral Research Project of Hebei Province (Grant Number B2020003029).

Data Availability Statement: Not applicable.

Acknowledgments: The authors would like to thank Hongxian Guo from Tsinghua University and Meng Li from Beijing Technology and Business University for everything they have done for this project. Special thanks to Xi Li for her English writing assistance.

Conflicts of Interest: The authors declare no conflict of interest.

\section{References}

1. Dejong, J.T.; Mortensen, B.M.; Martinez, B.C.; Nelson, D.C. Bio-mediated soil improvement. Ecol. Eng. 2010, 36, 197-210. [CrossRef]

2. Dejong, J.T.; Soga, K.; Kavazanjian, E.; Burns, S.E.; Paassen, L.A.V.; Qabany, A.A.; Aydilek, A.; Bang, S.S.; Burbank, M.; Caslake, L.F.; et al. Biogeochemical processes and geotechnical applications: Progress, opportunities and challenges. Geotechnique 2013, 63, 287-301. [CrossRef]

3. Chu, J.; Stabnikov, V.; Ivanov, V. Microbially induced calcium carbonate precipitation on surface or in the bulk of soil. Geomicrobiol. J. 2012, 29, 544-549. [CrossRef]

4. Cheng, L.; Cord-Ruwisch, R.; Shahin, M.A. Cementation of sand soil by microbially induced calcite precipitation at various degrees of saturation. Can. Geotech. J. 2013, 50, 81-90. [CrossRef]

5. Tittelboom, K.V.; Belie, N.D.; Muynck, W.D.; Verstraete, W. Use of bacteria to repair cracks in concrete. Cem. Concr. Res. 2009, 40, 157-166. [CrossRef]

6. Zhang, H.; Guo, H.; Li, M.; Cheng, X. Experimental research of microbial-induced clogging in sands. Ind. Constr. 2015, 45, 139-142.

7. Kang, C.H.; Kwon, Y.J.; So, J.S. Bioremediation of heavy metals by using bacterial mixtures. Ecol. Eng. 2016, 89, 64-69. [CrossRef]

8. Chen, X. Heavy metal immobilisation and particle cementation of tailings by biomineralisation. Environ. Geotech. 2017, 5, 107-113. [CrossRef]

9. Yang, J.; Pan, X.; Zhao, C.; Mou, S.; Achal, V.; Misned, F.A.A.; Mortuza, M.G.; Gadd, G.M. Bioimmobilization of heavy metals in acidic copper mine tailings soil. Geomicrobiol. J. 2016, 33, 261-266. [CrossRef]

10. Qabany, A.A.; Soga, K. Effect of chemical treatment used in MICP on engineering properties of cemented soils. Geotechnique 2013, 63, 331-339. [CrossRef]

11. Lee, M.L.; Ng, W.S.; Tanaka, Y. Stress-deformation and compressibility responses of bio-mediated residual soils. Ecol. Eng. 2013, 60, 142-149. [CrossRef]

12. Montoya, B.M.; Dejong, J.T. Stress-strain behavior of sands cemented by microbially induced calcite precipitation. J. Geotech. Geoenviron. Eng. 2015, 141, 04015019. [CrossRef] 
13. Deng, X.; Zongxuan, Y.; Yu, L.; Hao, L.; Jianye, F.; Benjamin, D.W. Experimental study on the mechanical properties of microbial mixed backfill. Constr. Build. Mater. 2020, 265, 120643. [CrossRef]

14. Muynck, W.D.; Belie, N.D.; Verstraete, W. Microbial carbonate precipitation in construction materials: A review. Ecol. Eng. 2009, 36, 118-136. [CrossRef]

15. Montoya, B.M. Bio-mediated soil improvement and the effect of cementation on the behavior, improvement, and performance of sand. Diss. Theses Gradworks 2012, 7, 209-223.

16. Umar, M.; Kassim, K.A.; Chiet, K.T.P. Biological process of soil improvement in civil engineering: A review. J. Rock Mech. Geotech. Eng. 2016, 8, 767-774. [CrossRef]

17. DeJong, J.T.; Fritzges, M.B.; Nüsslein, K. Microbially induced cementation to control sand response to undrained shear. J. Geotech Geoenviron. Eng. 2006, 132, 1381-1392. [CrossRef]

18. Hataf, N.; Baharifard, A. Reducing soil permeability using microbial induced carbonate precipitation (MICP) method: A case study of shiraz landfill soil. Geomicrobiol. J. 2020, 37, 147-158. [CrossRef]

19. Li, M.; Cheng, X.; Guo, H.; Yang, Z. Biomineralization of carbonate by terrabacter tumescens for heavy metal removal and biogrouting applications. J. Environ. Eng. 2015, 142, C4015005. [CrossRef]

20. Gai, X.; Sánchez, M. An elastoplastic mechanical constitutive model for microbially mediated cemented soils. Acta Geotech. 2019, 14, 709-726. [CrossRef]

21. Li, M.; Li, L.; Ogbonnaya, U.; Wen, K.; Tian, A.; Amini, F. Influence of fiber addition on mechanical properties of MICP-treated sand. J. Mater. Civ. Eng. 2015, 28, 04015166. [CrossRef]

22. Rajasekar, A.; Moy, C.K.S.; Wilkinson, S. MICP and advances towards eco-friendly and economical applications. IOP Conf. Ser. Earth Environ. Sci. 2017, 78, 012016. [CrossRef]

23. ISO 14040. Environmental management_Life cycle assessment_Principles and framework; ISO 14040, 2006.

24. Huntzinger, D.N.; Eatmon, T.D. A life-cycle assessment of Portland cement manufacturing: Comparing the traditional process with alternative technologies. J. Clean. Prod. 2009, 17, 668-675. [CrossRef]

25. Heede, P.V.D.; Belie, N.D. Environmental impact and life cycle assessment (LCA) of traditional and 'green' concretes: Literature review and theoretical calculations. Cem. Concr. Compos. 2012, 34, 431-442. [CrossRef]

26. Xu, X.; Guo, H.; Cheng, X.; Li, M. The promotion of magnesium ions on aragonite precipitation in MICP process. Constr. Build. Mater. 2020, 263, 120057. [CrossRef]

27. Li, L.; Amini, F.; Zhao, Q.; Li, C.; Ogbonnaya, U. Development of a flexible mold for bio-mediated soil materials. Geotech. Spec. Publ. 2015, 12, 2339-2348.

28. Li, M.; Wen, K.; Li, Y.; Zhu, L. Impact of oxygen availability on microbially induced calcite precipitation (MICP) treatment. Geomicrobiol. J. 2017, 35, 15-22. [CrossRef]

29. Pryshlakivsky, J.; Searcy, C. Fifteen years of ISO 14040: A review. J. Clean. Prod. 2013, 57, 115-123. [CrossRef]

30. IPCC. Guidelines for National Greenhouse Gas Inventories, Reference Manual; IPCC: Bracknell, UK, 1996.

31. Huijbregts, M.A.J.; Schöpp, W.; Verkuijlen, E.; Heijungs, R.; Reijnders, L. Spatially explicit characterization of acidifying and eutrophying air pollution in life-cycle assessment. J. Ind. Ecol. 2010, 4, 75-92. [CrossRef]

32. Jenkin, M.E.; Hayman, G.D. Photochemical ozone creation potentials for oxygenated volatile organic compounds: Sensitivity to variations in kinetic and mechanistic parameters. Atmos. Environ. 1999, 33, 1275-1293. [CrossRef]

33. Derwent, R.G.; Jenkin, M.E.; Saunders, S.M.; Pilling, M.J. Photochemical ozone creation potentials for organic compounds in northwest Europe calculated with a master chemical mechanism. Atmos. Environ. 1998, 32, 2429-2441. [CrossRef]

34. Wenyou, L.; Lumei, Z. Principle of Chemistry; Chongqing University Press: Chongqing, China, 2015.

35. Chen, H.J.; Huang, Y.H.; Chen, C.C.; Maity, J.P.; Chen, C.Y. Microbial induced calcium carbonate precipitation (MICP) using pig urine as an alternative to industrial urea. Waste Biomass Valorization 2019, 10, 2887-2895. [CrossRef]

36. Choi, S.G.; Wu, S.; Chu, J. Biocementation for sand using an eggshell as calcium source. J. Geotech. Geoenviron. Eng. 2016, 142, t06016010. [CrossRef]

37. Cheng, L.; Shahin, M.A.; Cord-Ruwisch, R. Bio-cementation of sandy soil using microbially induced carbonate precipitation for marine environments. Geotechnique 2014, 64, 1010-1013. [CrossRef]

38. Zhao, Q.; Li, L.; Li, C.; Li, M.; Amini, F.; Zhang, H. Factors affecting improvement of engineering properties of MICP-treated soil catalyzed by bacteria and urease. J. Mater. Civ. Eng. 2014, 26, 04014094. [CrossRef]

39. Paassen, L.A.V.; Ghose, R.; Linden, T.J.M.V.D.; Star, W.R.L.V.D.; Loosdrecht, M.C.M.V. Quantifying biomediated ground improvement by ureolysis: Large-scale biogrout experiment. J. Geotech. Geoenviron. Eng. 2010, 136, 1721-1728. [CrossRef]

40. Ismail, M.A.; Joer, H.A.; Sim, W.H.; Randolph, M.F. Effect of cement type on shear behavior of cemented calcareous soil. J. Geotech. Geoenviron. Eng. 2002, 128, 520-529. [CrossRef]

41. Gomez, M.G.; Dejong, J.T. Engineering properties of bio-cementation improved sandy soils. Grouting 2017, 23-33.

42. Cheng, X.; Ma, Q.; Yang, Z.; Zhang, Z.; Li, M. Dynamic response of liquefiable sand foundation improved by bio-grouting. Chin. J. Geotech. Eng. 2013, 35, 1486-1495.

43. Amarakoon, G.G.N.N.; Satoru, K. Factors affecting sand solidification using MICP with pararhodobacter sp. Mater. Trans. 2017, 59, 72-81. [CrossRef]

44. Choi, S.-G.; Wang, K.; Chu, J. Properties of biocemented, fiber reinforced sand. Constr. Build. Mater. 2016, 120, 623-629. [CrossRef]

45. Rong, H.; Qian, C. Characterization of microbe cementitious materials. Chin. Sci. Bull. 2012, 57, 1333-1338. [CrossRef] 
46. Yang, D.; Fan, L.; Shi, F.; Liu, Q.; Wang, Y. Comparative study of cement manufacturing with different strength grades using the coupled LCA and partial LCC methods-A case study in China. Resour. Conserv. Recycl. 2016, 119, 60-68. [CrossRef]

47. Li, C.; Gong, X.Z.; Cui, S.P.; Wang, Z.H.; Zheng, Y.; Chi, B.C. $\mathrm{CO}_{2}$ emissions due to cement manufacture. Mater. Sci. Forum 2011, 1264, 181-187. [CrossRef]

48. Dandautiya, R.; Singh, A.P. Utilization potential of fly ash and copper tailings in concrete as partial replacement of cement along with life cycle assessment. Waste Manag. 2019, 99, 90-101. [CrossRef] [PubMed]

49. Gong, Z.; Zhang, Z. A study on embodied environmental profile during the life cycle of cment. China Civ. Eng. J. 2004, 37, 86-91.

50. Tan, Q.; Guo, H.; Chen, X. Experimental study of strength and durability of microbial cement mortar. Ind. Constr. 2015, 45, 42-47.

51. Feng, S.T.; Lu, H.L.; Ye, F. Application of plaster powder in fired common brick strength testing. Adv. Mater. Res. 2014, 1030-1032, 705-708. [CrossRef]

52. Sun, B.; Liu, Y.; Nie, Z.; Zhang, Y.; Gao, F. Exergy-based model for quantifying land resource in China: A case study of sintered brick. Int. J. Exergy 2014, 15, 429-446. [CrossRef]

53. Kennedy, C.; Steinberger, J.; Gasson, B.; Hansen, Y.; Hillman, T.; Havránek, M.; Pataki, D.; Phdungsilp, A.; Ramaswami, A.; Mendez, G.V. Methodology for inventorying greenhouse gas emissions from global cities. Energy Policy 2009, 38, $4828-4837$. [CrossRef]

54. Lan, M.; Nie, S.; Wang, J.; Zhang, Q.; Chen, Z. A state-of-the-art review on lime-based mortars for restoration of ancient buildings. Mater. Rep. 2019, 33, 1512-1516.

55. Kesimal, A.; Yilmaz, E.; Ercikdi, B. Evaluation of paste backfill mixtures consisting of sulphide-rich mill tailings and varying cement contents. Cem. Concr. Res. 2004, 34, 1817-1822. [CrossRef]

56. Zhang, Q.; Zhang, J.; Huang, Y.; Feng, J. Backfilling technology and strata behaviors in fully mechanized coal mining working face. Int. J. Min. Sci. Technol. 2012, 22, 151-157. [CrossRef]

57. Deng, X.; Zhang, J.; Klein, B.; Zhou, N.; de Wit, B. Experimental characterization of the influence of solid components on the rheological and mechanical properties of cemented paste backfill. Int. J. Miner. Process. 2017, 168, 116-125. [CrossRef]

58. Deng, X.; Klein, B.; Tong, L.; Wit, B.D. Experimental study on the rheological behavior of ultra-fine cemented backfill. Constr. Build. Mater. 2018, 158, 985-994. [CrossRef] 